\title{
Mediating Effect of Psychological Contract in the Relationship between Learning and Development Initiatives and Engineers' Intention to Stay
}

\author{
Roya Anvari ${ }^{1}$, Nurul Syafiqa binti Jisma Huzaid ${ }^{1}$, Seyyed Abolfazl Miri ${ }^{1} \&$ Siavash Hosseinpour Chermahini ${ }^{2}$ \\ ${ }^{1}$ Department of Human Resource Development, Faculty of Management, Universiti Teknologi Malaysia, Skudai, \\ Johor Bahru, Malaysia \\ ${ }^{2}$ Department of Bioprocess Engieering, Faculty of Chemical Engineering, Universiti Teknologi Malaysia, \\ Skudai, Johor Bahru, Malaysia \\ Correspondence: Roya Anvari, Department of Human Resource Development, Faculty of Management, \\ Universiti Teknologi Malaysia, 81310 Skudai, Johor Bahru, Malaysia. E-mail: roya.anvari@utm.my
}

Received: September 7, 2013 Accepted: November 20, $2013 \quad$ Online Published: November 22, 2013

doi:10.5539/res.v5n5p 233

URL: http://dx.doi.org/10.5539/res.v5n5p233

\begin{abstract}
The study sets out to explore the role of psychological contract in the relationship between learning and development (L\&D) factors and intention to stay within engineering firms, based on the social exchange theory, a popular framework about psychological contract and maintenance of the employee-employer relationship. The exploration of current L\&D (individual and organizational) initiatives will contribute theoretically as well as empirically towards an understanding of how to retain workers by examining a range of variables, from personal and organizational factors. The methodology used in this conceptual paper is a critical literature review that sparks argument on the subject discoursed. This paper addresses the gap by providing a discussion on the challenges of employee retention. The evaluation using $L \& D$ initiatives will not only create a holistic evaluation process, but it will also assist in fostering a sense of obligation to stay among employees in the organization.
\end{abstract}

Keywords: learning and development, intention to stay, psychological contract

\section{Introduction}

Dato Sri Mohd Najib bin Tun Abdul Razak (2010) in his speech titled Introducing the Motion to Table the Tenth Malaysia Plan quoted that the goal of achieving developed nation status by 2020 has increasingly been linked to the fostering of knowledgeable human resources. The Prime Minister said the delivery and effective government service is closely linked to the quality of human resource. He also stated that the employer should be responsible on providing meticulous effort within the business community to upscale all aspects of operations and management, including the development of a value-added workforce. It is argued that by creating a group of highly knowledgeable human resource as a catalyst for development and innovation, this would help the nation to become a high income nation. The notion of psychological contract in aligning employees with the organization's culture, motivating them and gaining their commitment, is important to develop employees and upgrade their skills, knowledge and abilities.

Under the Tenth Malaysia plan 2011-2015, both the private and public sector have been encouraged to invest in non-physical infrastructure and provide services such as skills training. In the current plan, 40 per cent of total funding is being allocated to this purpose. Focus is given to skill development programmes, research \& development activities and venture capital funding geared towards promoting a higher level of innovation in the country. The issue here is: despite numerous training budgets have been released to both public and private sector since the Ninth Malaysia Plan (Dato Seri Abdullah bin Haji Ahmad Badawi, 2006), organizations still face a crucial shortage of engineers as a result in high employee turnover. These organizations are not aware of their own strengths and weaknesses in terms of deploying Learning and Development (L\&D) initiatives (Harrison, 2005). The training and development activities have increased since the budget allocation of these activities, but the retention of knowledge workers is not in line with the Learning and Development initiative. This issue was highlighted again in the First Strategic Thrusts in the 10th Malaysia Plan consists of improving efforts for human capital in various sectors and this has opened up big opportunities for these workers to continually learn and 
develop themselves.

According to Lim (2001) Malaysians are only willing to stay with their current organizations for less than three years. Thus, retention of skill workers is seen as vital to the national policy approach to developing human capital. According to Hay (2002), the main rationale employees' turnover is due to discontent on how their competences are developed. Therefore, even if training and development activities were believed to be effective, organization might still not be effective because managers do not know how to implement these activities successfully in the organization. So, human resource managers' roles in effective implementation of L\&D achieved through intensive training and supportive environment that promotes personal competence, adoptability, and retention. According to Streumer (2006) many organizations are afraid to roll the dice and invest in something of which the effectiveness they are unsure of. Therefore, determining the best L\&D initiatives, methods or practices need to be investigated, now more than ever because of the growing interest of HRMs in retaining has been discussed theoretically and rhetorically (Abdull Rahman, 2012) but there are not many researches captured the relationship in actual work-setting. Not only that, the role of psychological contract as a linking pin may be a logical reason on why currently only 23 per cent of Malaysian workforce is highly skilled.

\section{Literature Review}

Psychological contract is defined "as the beliefs individuals hold regarding the terms and conditions of the exchange agreement between themselves and their organizations" (Rousseau, 1993) or an "individual's belief in the terms and conditions of a reciprocal exchange agreement between the focal person and another group" (Rousseau, 1993). In other words, "psychological contracts refer to employees' perceptions of what they owe to their employers and what their employers owe to them" (Robinson, 1996). To identify best practices which can lead to effectiveness of L\&D initiatives, it is important to understand the middle-range learning models at the individual and organizational level. As Figure 1 illustrates six crucial assumption of core adult learning principles must be established in order to understand how employee learn, why employees need to learn, and how it will benefit them (Knowles, 1998). Kolb's experiential learning is another model consists of four different learning styles such as converger, diverger, assimilator, and accommodator (1984). All of these styles are important in determining individual preferred learning styles, thus influencing the effectiveness of learning transfer. At organizational level, the learning organization strategy model (Illeris, 2003) emphasizes more on how employee best learn in the working environment. So, all of these theories argue about different approaches in implementing L\&D initiatives effectively.

According to Rhoades and Eisenberger (2002), human resource practices can influence employees' retention. The research literature provides strong support for the influence of psychological contract on L\&D and employee retention. Eisenberger et al. (2001) identifies that learning factor plays a key role in managing, developing, and retaining employees. In studies of the employee retention problem, there has been a rather heavy emphasis on management responses. The central problematic of the human resource literature tends to be defined as that of attracting, retaining, and developing staff (see for example Schulder and Jakson, 2007). The generalized solutions offered tend to be couched in terms of intention to stay with the organization, through the provision of long-term rewards such as those based on career planning and management (Baruch, 2004). There is lower and limited evidence as to which human resource practice influence employees' long term retention, as empirical studies have focused mainly on antecedents for quitting rather than on explanations of employees' intention to stay with an organization. In the case of Malaysian employees, it has been suggested that retention strategies based on intrinsic rewards may have limited success. Malaysians are reported to be money oriented (Abdull Rahman, 2012); hence more inclined to job hope and change employers with little hesitation in pursuit for higher wages (Chew, 2005). Nevertheless, in studies based on the Malaysian context, a range of organizational strategies has been found to foster employee retention (Samad \& Hassan, 2007; Chew \& Wong, 2008). These studies found that training creation, career mentoring, completive salary, and promotion opportunities may indeed influence employees' commitment or turnover intention. Other studies outside of Malaysia also found that training (Lee \& Maurer, 1997) and career management (Inkson, 2007) are all linked to reducing turnover, enhancing commitment and retention of employees. These finding suggest that organizations can improve retention of their key employees by effectively implement certain training and learning strategies. It is reasonable to argue that the benefits of long term retention of knowledge workers outweigh the cost losing and replacing them. The cost of replacing leavers can be high as companies not only suffer the loss of training investment, but turnover also can affect employment relationship.

Five research questions that can be derived from the reviews are: a) can Malaysian engineers' turnover behavior be modified by $L \& D$ professionals based on organizational and individual factors? b) to what extent do Malaysian engineers value learning and development opportunities and psychological contract, and to what 
extent are they experiencing a need for learning and developing opportunities and psychological contract? c) can social exchange theory, particularly theories of the effects of perceptions of psychological contract, provide an insight into L\&D (organizational and individual) factors that would influence engineers' intention to stay with an organization? d) what case can be made for Malaysian organizations to adopt learning and development initiatives designed to foster engineers' skill development and retention?

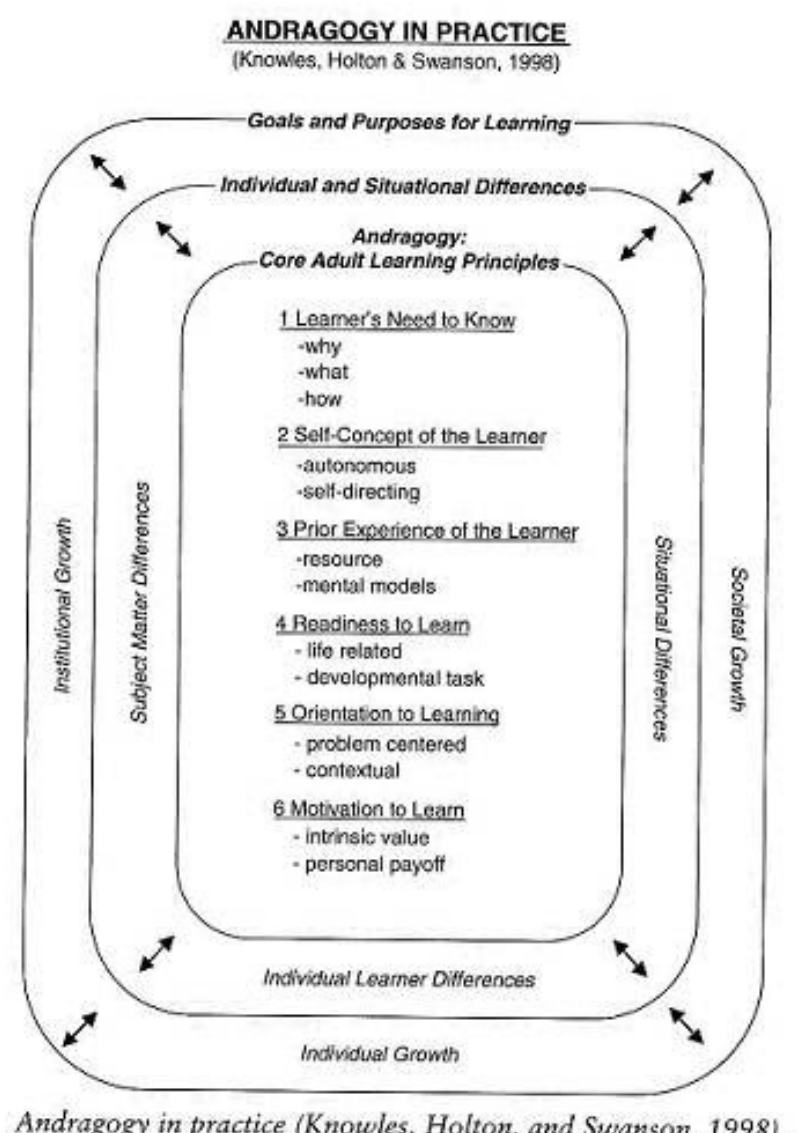

Figure 1. Andragogy in practice (Knowles et al., 1998)

\section{Description of Methodology}

Through a mixed-method design based on survey of engineers as well as interviews with managers, the study will combine L\&D perspectives on the factors shaping engineers' turnover intentions and their causes. The survey will indicate a link between L\&D (organizational and individual) factors, psychological contract, and engineers' turnover intentions and their causes. Interviews with engineers will reflect the influence of determinant of L\&D initiatives in some cases with little sense of reciprocity. Combining these methods will enable the researcher to generate a huge amount of data which increase the robustness of this study. First, human resource managers from 10 Johor manufacturing companies will be chosen to fill up the questionnaire. A subsample of engineers will be interviewed. The manufacturing industry will be chosen because it is identified as the main employer for engineers (DOS, 2010). The questionnaire is based on the developed L\&D initiatives model, psychological contract, and turnover intention (Coyle-Shapiro and Shore, 2007). SPSS package (Version 18) for quantitative data will be used, while the qualitative data will employ the use of Nvivo. The outcomes of the interview sessions will provide evidence regarding type and responsibility to L\&D initiatives, turnover and retention problem and strategies in participant's company. It will provide a description of L\&D initiatives in Malaysian organization, specially engineering firms.

\section{Expected Findings and Conclusion}

The exploration of current L\&D (individual and organizational) initiatives will contribute theoretically as well as empirically towards an understanding of how to retain workers by examining a range of variables, from personal and organizational factors. Besides that, it contributes to the modelling of the relationship between L\&D 
initiatives and employee retention, by examining the mediating effect of psychological contract on this relationship. In this paper, the authors have presented a proposition to study on to what extent do Malaysian engineers value learning and development opportunities and psychological contract, and to what extent are they experiencing a need for learning and developing opportunities and psychological contract. Through an investigation of the different types of firms, it would be possible to identify the challenges of employee retention and the mismatch between L\&D professionals and retention strategies with engineer's needs, wants, and expectations (psychological contract) in relation to their retention. Implementation of this program will be able to develop a first world talent base that will be one of the initiatives to drive Malaysia into a high income nation.

\section{Acknowledgements}

We would like to extend our appreciation to the Ministry of Higher Education (MOHE, vote number: Q.J130000.2729.00k30) for funding this project and our acknowledgement to the Research Management Center, Universiti Teknologi Malaysia for their support in managing this research.

\section{References}

Abdull Rahman, R. H. (2012). Malaysian firms' role in retaining engineers. The Economic and Labour Relations Review, 23(4), 57-78.

Chew Y. T., \& Wong, S. K. (2008). Effects of career mentoring experience and perceived organizational support on employee commitment and intention to leave: a study among hotel workers in Malaysia. International Journal of Management, 25(4), 692-700.

Coyle-Shapiro, J. A. M., \& Shore, L. (2007). The employee-organization relationship: Where do we go from here? Human Resource Management Review, 17, 166-179.

Dato Seri Abdullah bin Haji Ahmad Badawi. (2006, March). Introducing the motion to table the Ninth Malaysia Plan (2006-2010). Speech presented in the Dewan Rakyat, Kuala Lumpur, Malaysia.

Dato Seri Mohd Najib bin Tun Abdul Razak. (2010, June). Introducing the motion to table the Ninth Malaysia Plan (2011- 2015). Speech presented in the Dewan Rakyat, Kuala Lumpur, Malaysia.

DOS. (2010). Statistics handbook Malaysia. Putrajaya, Malaysia: department of statistics.

Guest, D. E. (1998). Is the psychological contract worth taking seriously? Journal of Organizational Behavior, 19(SI), 649-664.

Harrison, R. (2005). Learning and development. revision guide, 2005 (4th ed.). London: Chartered Institute of Personnel and Development.

Hay, M. (2002). Strategies for survival in the war of talent. Career Development International, 6(1), 52-55.

Illeris, K. (2003). Workplace learning and learning theory. Journal of Workplace Learning, 15(4), 167-178.

Knowles, M. (1998). The Adult Learner: the Definitive Classic in Adult Education and Human Resource Development. Houston, TX: Gulf Publishing.

Kolb, D. (1984). Experiential Learning: Experience as the Source of Learning and Development. Englewood Cliffs, New Jersey: Prentice Hall.

Lee, T. W., \& Maurer, S. D. (1997). The retention of knowledge workers with the unfolding model of voluntary turnover. Human Resource Management Review, 7, 247-275.

Lim, C. P. (2001). Object of the activity systems as a major barrier to the creative use of ICT in school. Australian Journal of Educational Technology, 17(3), 295-312.

Robinson, S. L. (1996). Trust and breach of the psychological contract. Administrative Science Quarterly, 41, 574-599.

Rousseau, D. M., \& Parks, J. M. (1993). The contracts of individuals and organizations. In L. L. Cummings, \& B. M. Staw (Eds.), Research in Organizational Behavior. JAI Press, Greenwich.

Samad, S., \& Hassan, Z. (2007). Assesing the effects of job satisfaction and psychological contract on organizational commitment among employees in Malaysia SMEs. The $4^{\text {th }}$ SMEs in global economy conference, 9-10 July.

Schuler, R. S., \& Jackson S. E. (2007). Strategic Human Resource Management: A Reader. London: Blackwell Publishers.

Streumer J. N. (2006). Work-related learning. Springer, Dordrecht, the Netherlands. 


\section{Copyrights}

Copyright for this article is retained by the author(s), with first publication rights granted to the journal.

This is an open-access article distributed under the terms and conditions of the Creative Commons Attribution license (http://creativecommons.org/licenses/by/3.0/). 